that Harsa of Gauda, Uḍa, Kalinga, etc., whose daughter Räjyamatī, "born in the Bhagadatta-räjakula," was married by Jayadeva-Paracakrakāma of Nepāl (Ind. Ant., vol. ix, p. 179), was almost certainly a king of Prāgjyotiṣa. In fact, he most probably was the Harișa (or Harșa) of the Tejpur grant (Journ. As. Soc. Bengal, vol. ix, p. 767), who would be thus placed in the first half of the eighth century A.D. ${ }^{1}$

Besides, in line 13, instead of Kaumr-anvaya, the photoetching suggests the reading Bhaum-ânvaya. Kaumra is an impossible word, which could not be derived from Kumāra. On the other hand, as the family derived its origin from Viṣnu and the Earth, it may well have been called the Bhauma-variśa, either after the Earth herself or after her and Viṣnu's son Naraka (Bhauma), the father of Bhagadatta, just as in the Harsa-carita it is called the Vaișnava-vainśs after Viṣu. ${ }^{2}$

In the admirable English translation of the Harşa-carita, the prince of Prāgjyotișa who sends a messenger to Harșa is called "Bhāskaradyuti, otherwise named Bhāskaravarman," and is described as heir-apparent (kumāra). But I still believe that Kumāra was the prince's name, and that he was surnamed Bhāskaravarman, because, as the poet says, he possessed the sun's splendour (bhäskara-dyuti).

F. KIELHORN.

12. TATHĀGata.

Wakefield.

March 7, 1898.

DEAR SIR,-In connection with Mr. Chalmers' article on the term 'tathāgata,' in the January number of the Journal, the Tibetan rendering of the title may be noticed. It is

1 Jayadeva-Paracakrakāma's inscription is dated in (Harșa)-samvat 153, i.e. about A.D. 758. The known inscriptions of the kings of Prägjyotișa are not dated, except in regnal years.

2 The Palla dynasty belonged to the solar, the Sena dynasty to the lunar race. 
de-bz'in $\gamma s^{\prime}$ egs-pa. The verb $\gamma s^{\prime}$ 'egs-pa is highly honorific, and is constantly used in books, rarely colloquially, of the great saints and Buddhas. It signifies both to 'come' and to 'go,' and as far as its grammatical form is concerned might be taken in the title as either past, present, or future. de-bz'in means 'according to that' or 'according to those.' Jaeschke renders the phrase as 'he that walks in the same ways (as his predecessors),' but it could also mean 'he that has walked.' bde(-bar) ys'egs(-pa) is the regular translation of 'sugata.' The Tibetan term evidently covers the first and second of Buddhaghosa's interpretations, to the exclusion of all others.

Dr. Waddell enumerates seven medical tathāgatas, with whom Gautama is associated as the eighth. This is a rather striking parallel to Buddhaghosa's eighth explanation; but it is probably merely an accidental coincidence, since none of the Tibetan words have the slightest connection with any term signifying 'physic' or 'physician.'

Of course the Tibetan form cannot in any way claim to be authoritative, but it clearly shows what meaning was attached to the term by the scholars who made the translation (about the eighth century A.D.), and as such it seems interesting enough to be mentioned.-I am, yours truly,

F. B. Shawe.

\section{Samudra Gupta.}

Dear Sir, - Under date the 11th February, Hofrath Professor Bükler writes to me as follows:-

"I would call your attention to an important point connected with Harișena's Prasasti on the Allahabad Pillar.

"This document is not a posthumous eulogy of Samudra Gupta, as Fleet asserts, following Prinsep and Mill. His translation of the passage (towards the end) about the wanderings of Samudra Gupta's Fama is against the rules of Sanskrit grammar. 